Volume 1, Nomor 2, Maret 2021, hlm 74-87

BEMAS: JURNAL BERMASYARAKAT

p ISSN 27455866 | e ISSN 27457958

\title{
UJI KOMPETENSI PENGUASAAN SOFTWARE UNTUK SOLUSI BISNIS DI WILAYAH KAB. BOGOR SEBAGAI UPAYA PENINGKATAN SKILL SMK JURUSAN RPL
}

\author{
Iskandar $^{1 *}$, Mohamad Anas Sobarnas ${ }^{2}$ \\ ${ }_{1 *, 2}$ Program Studi Teknik Informatika, Sekolah Tinggi Teknologi Muhammadiyah Cileungsi, Bogor, Jawa \\ Barat-Indonesia \\ Email:*iskandar@sttmcileungsi.ac.id, anas@sttmcileungsi.ac.id
}

\author{
INFORMASI ARTIKEL \\ Article History: \\ Submission: 04-03-2021 \\ Revised: 15-03-2021 \\ Accepted: 18-03-2021 \\ * Korespondensi: \\ Iskandar \\ iskandar@sttmcileungsi.ac.id
}

\begin{abstract}
ABSTRAK
Penguasaan software untuk solusi bisnis pada era digital ini untuk siswa Sekolah Menengah Kejuruan (SMK) pada Jurusan Rekayasa Perangkat Lunak adalah suatu syarat mutlak harus dikuasai oleh setiap siswa. Karena lulusan SMK sudah diproyeksikan saat lulus nanti sudah bisa mengerjakan proyek perangkat lunak nantinya. Namun kenyataannya masih banyak lulusan kejuruan yang masih belum bisa optimal terjun dalam proyek perangkat lunak untuk tujuan pembuatan software dalam pemecahan solusi untuk bisnis dikarenakan kurang match antara materi praktis yang diberikan di sekolah dengan kebutuhan Dunia Usaha (DU/DI). Dengan melihat latar belakang tersebut Dinas Pendidikan Wilayah 1 Kabupaten Bogor mengadakan Lomba Kompetensi Siswa (LKS) SMK IT Software Solution For Business untuk tingkat SMK. Tujuan dari lomba Kompetensi pada siswanya supaya bisa bersaing dalam penguasaan software dalam solusi untuk bisnis. Metode pembelajaran atau modul pembelajaran yang diberikan kurang menyesuaikan pada kebutuhan industri, untuk itu perlu adanya metode dalam menganalisis proyeksi cakupan pembelajaran dikelas dengan kebutuhan pada dunia kerja yang ada pada sekolah SMK Jurusan RPL. Penilain praktis kompetensi siswa ini menggunakan taksonomi pembelajaran Bloom, PEST, Ward Peppard, SWOT dan CSF sehingga menghasilkan suatu konsep perancangan materi praktis dan tool pendukung untuk pembelajaran pada institusi sekolah sehingga siswa jurusan RPL sehingga mempunyai keahlian di bidang Teknologi Informasi.
\end{abstract}

Kata Kunci: Software, SMK, SWOT, CSF, RPL

ABSTRACT

Mastery of software for business solutions in this digital era for Vocational High School (SMK) students in the Software Engineering Department is an absolute requirement that every student must master. Because SMK graduates are projected to be able to work on software projects later when they graduate. But in reality there are still many vocational graduates who are still unable to optimally engage in software projects for the purpose of making software in solving solutions for businesses due to the lack of match between the practical material provided in school with the needs of the Business World (DU/DI). By looking at this background, the Bogor District 1 Education Office held a Vocational School IT Software Solution For Business Student Competency Contest (LKS) for the SMK level. The aim of the Competency competition is for students to compete in software 
mastery in solutions for business. The learning method or learning module provided does not adapt to the needs of the industry, for that it is necessary to have a method in analyzing the projected scope of learning in class with the needs of the world of work that exist in SMK RPL Department. This practical assessment of student competencies uses Bloom, PEST, Ward Peppard, SWOT and CSF learning taxonomies so as to produce a practical material design concept and supporting tools for learning in school institutions so that students majoring in RPL have expertise in the field of Information Technology.

\section{PENDAhULUAN}

Proses penilaian institusi sekolah terkait dengan program pendidikan yang disajikan oleh institusi sekolah dapat dilakukan melalui pengujian lomba kompetensi praktis dalam pembuatan program [1] software solution for business adalah suatu hal suatu hal yang mutlak harus dilakukan oleh institusi dalam rangka mengukur serapan pembelajaran secara psikomotorik sehingga dimiliki oleh setiap siswa sekolah Menengah Kejuruan (SMK)[2] di Kab Bogor. Penilaian kompetensi keahlian dalam pembuatan software solution for business berbeda dengan mata pelajaran matematika dan pelajaran yang lainnya karena penilaian praktis pemrograman memerlukan banyak keahlian sebagai contoh bahasa pemrograman dan metode pemrograman termasuk dengan penggunaan sintaks dan logika dalam pemrograman dalam penyelesaian solusi dalam bidang bisnis. Dengan bertambahnya siswa di sekolah membutuhkan metode dan kesiapan infrastruktur dalam penyiapan siswa yang berkompetensi di bidang software solution for business.

Pemrograman komputer adalah kemampuan bagaimana membuat code-code program menggunakan bahasa tingkat tinggi dengan mengikuti standar sintaks dari bahasa pemrograman tersebut sehingga dapat dijalankan dalam pada sistem platform tertentu dalam rangka penyelesaian masalah dalam bidang industri atau kehidupan sehari-hari[3]. Dalam aktivitas seorang programmer selain pemahaman sintaks dan semantik diperlukan pula keahlian dalam mendesain program dalam pemahaman logika berpikir secara abstrak dan berpikir secara logika dalam pemecahan masalahnya. Sehingga dengan kata lain seorang programmer harus memiliki banyak keterampilan dan pengetahuan dalam melakukan tugas dan fungsinya.

Sekolah Menengah Kejuruan (SMK) biasanya memiliki jurusan khusus dalam pemrograman bidang komputer salah satunya jurusan rekayasa perangkat lunak (RPL) dalam kelas ini setiap siswa benar-benar mempelajari bahasa pemrograman dari mulai sintaks, semantik, coding, debug dan deployment dari bahasa pemrograman yang dipelajari, namun dengan sebanyak materi tentang pemrograman sampai dengan software yang baik bisa dihasilkan memerlukan keseriusan semua pihak baik dari siswa dan tentunya pihak manajemen penyelenggara sekolah dalam menyiapkan sarana dan prasarana yang menunjang peningkatan dan animo belajar siswa pada pelajaran ini.

Selain itu manajemen perlunya melakukan kerjasama dengan pelaku industri tentang profil lulusan yang akan dikeluarkan sekolah terkait kompetensi pemrograman. Namun yang selama ini kadangkadang pihak penyelenggara pendidikan kompetensi siswa kadang-kadang kurang match dengan kebutuhan dunia industri[4][5], karena kompetensi programer yang berbeda misalnya yang dipelajari bahasa pemrograman A sedangkan yang dibutuhkan di dunia usaha program B, disini perlunya melakukan kajian yang komprehensif dalam menentukan produk pelajaran sehingga profil lulusan ini bisa diperlukan di dunia industri, karena kalau profil lulusan tidak bisa diserap sebagai tenaga programmer di dunia industri akan menyebabkan kelebihan tenaga programmer bahasa tertentu[6]. Hal 
Uji Kompetensi Penguasaan Software Untuk Solusi Bisnis di Wilayah Kab. Bogor

Sebagai Upaya Peningkatan Skill SMK Jurusan RPL

ini salah satu kelemahan yang dialami oleh beberapa penyelenggara pendidikan yang diakibatkan oleh kesulitan mencari tenaga ahli/pengajar dalam bahasa pemrograman yang dibutuhkan oleh pelaku industri karena tentunya kalau tenaga profesional akan sulit untuk didatangkan manajemen sekolah.

Selain dari permasalahan kesulitan dari tenaga ahli yang mengajar pada bidang pemrograman tertentu tentunya adalah kadang-kadang belum adanya infrastruktur untuk pemrograman yang standar dalam menyiapkan produk pelajaran yang diminati di dunia industri contohnya tentang kesiapan software pendukung, sistem database yang mendukung, spesifikasi dari perangkat keras sehingga ini akan menjadi kendala dalam penyiapan programer yang berkualitas[7].

\section{METODE}

Metode yang digunakan dalam penelitian ini menggunakan metode ward and peppard dan taksonomi bloom sedangkan untuk analisis menggunakan PEST, CSF dan SWOT.

a) Perencanaan Strategi.

Perencanaan pada institusi manajemen sekolah merupakan strategi jangka panjang dalam mengelola semua sumber daya dalam mencapai tujuan dari manajemen, dimana strateginya sebagai berikut:

1) Distinctive competence: suatu tindakan yang dilakukan oleh manajemen sekolah agar bisa melakukan kegiatan operasional supaya lebih baik dibandingkan dengan pesaingnya.

2) Competitive advantage: Suatu kegiatan yang lebih menonjol dan unik yang dikembangkan oleh manajemen agar terlihat lebih unggul dengan para pesaingnya.

b) Perencanaan strategis teknologi informasi perusahaan.

Perencanaan strategis merupakan analisis yang sistematis tentang rumusan dari kebijakan pada organisasi pengelola sekolah dalam pemanfaatan teknologi informasi untuk tujuan menjaga keberlangsungan manajemen pengelola sekolah SMK dan bisa bersaing dalam menyajikan pendidikan yang kompetitif dari pesaing sesama penyelenggara pendidikan.

c) Analisis PEST.

Analisis PEST menurut [8].

1) Politik: terkait dengan peraturan pemerintah dan kebutuhan, kompetensi, dan standar lulusan SMK jurusan RPL dibutuhkan di perusahaan atau DU/DI.

2) Ekonomi: terkait pada faktor yang mempengaruhi daya beli masyarakat akan peningkatan pendidikan pada setiap keluarga.

3) Sosial: terkait pada kesadaran masyarakat terhadap pentingnya pendidikan dalam sebuah keluarga untuk peningkatan tatanan sosial bermasyarakat.

4) Teknologi: merupakan kondisi pemanfaatan Teknologi ICT yang sedang digunakan terbaru yang dibutuhkan di bidang pengembangan perangkat lunak (S/W) yang dibutuhkan di perusahaan atau di dunia pengembangan software.

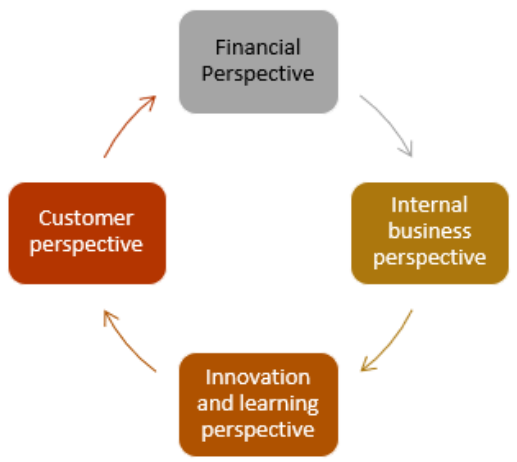

Gambar 1. Rencana strategis sistem informasi. 
Berikut penjelasan pada gambar 1 .

a) Financial perspective: menggambarkan kondisi kemampuan finansial manajemen yang menentukan kelangsungan institusi. Bagaimana strategi yang bisa mendatangkan keuntungan/profit secara ekonomi pada manajemen sekolah.

b) Internal Business Perspective: kegiatan institusi manajemen dalam memenuhi tuntutan dari pegawai dan mitra usaha.

c) Customer perspective: bagaimana siswa memandang manajemen sekolah dalam hal mutu pendidikan sekolah, relasi dengan DU/DI dan peningkatan mutu.

d) Innovation and learning Perspective: hal ini untuk mencapai visi masa depan.

Bagaimana manajemen sekolah dalam meng-upgrade skill lulusan jurusan SMK RPL masa akan

e) Analisis SWOT

Critical Succes Factor (CSF) bertujuan untuk mempresentasikan sumber daya manajemen kekurangan dan kelebihan perusahaan dalam pengelolaan manajemen sekolah.

Pembuatan suatu rencana strategis yang baik memerlukan langkah-langkah dalam penelitian. Adapun langkah-langkah dalam PkM menggunakan metode Ward Peppard dengan metode.

a. Identifikasi proses bisnis dengan melakukan observasi, interview dan studi literatur dokumendokumen lembaga.

b. Dari hasil observasi, wawancara dan membaca dokumen-dokumen lembaga, maka dikumpulkan semua data untuk dilakukan analisa.

c. Analisis terkait kondisi lingkungan baik internal maupun eksternal.

d. Berdasarkan analisis dilakukan perumusan strategi sesuai kebutuhan Teknologi RPL pada masa yang akan datang.

e. Membuat kesimpulan hasil penelitian.

2.1 Fungsi kurikulum SMK.

Fungsi kurikulum SMK menurut [9] dalam sistem pembelajaran di sekolah kejuruan.

a. Kurikulum adalah produk, artinya kurikulum hasil rancangan dari skema pendidikan oleh pihak yang berwenang.

b. Kurikulum adalah program, artinya alat yang digunakan institusi sekolah dalam mencapai tujuan kompetensi pendidikan akan dicapai.

c. Kurikulum adalah rangkaian pendidikan yang akan diikuti oleh siswa.

d. Kurikulum adalah rangkaian pengalaman siswa dalam rangka mempersiapkan keterampilan secara praktis dan akademis dalam menerapkan ilmunya setelah lulus.

\subsection{Kompetensi Lulusan SMK.}

Kompetensi lulusan menurut[10] merupakan perpaduan dari ilmu pengetahuan, keterampilan, nilai dan sikap direfleksikan dalam kebiasaan berpikir dan bertindak seorang siswa atau dengan kata lain bahwa kompetensi adalah bagaimana seorang siswa dapat menggunakan kemampuan berpikir dan bersikap dengan menggunakan ilmu pengetahuan yang dimiliki dalam menyelesaikan suatu tugas atau tanggung jawabnya [11].

\subsection{Pendidikan kompetensi menurut taksonomi bloom.}

Kompetensi merupakan tindakan cerdas yang dimiliki seseorang dalam mengimplementasikan hasil pendidikan secara praktis dan akademik sehingga mampu melakukan tugasnya pada bidang pekerjaan tertentu. Taksonomi Bloom menurut[12] berdasarkan ranah kognitif terdiri Pengetahuan (Knowledge)/C-1, Pemahaman (Comprehension)/C-2, Penerapan (Application) /C-3, Analisis (Analysis)/C-4, Sintesis (Synthesis)/C-5 , Evaluasi (Evaluation)/C-6[12]. 
Uji Kompetensi Penguasaan Software Untuk Solusi Bisnis di Wilayah Kab. Bogor

Sebagai Upaya Peningkatan Skill SMK Jurusan RPL

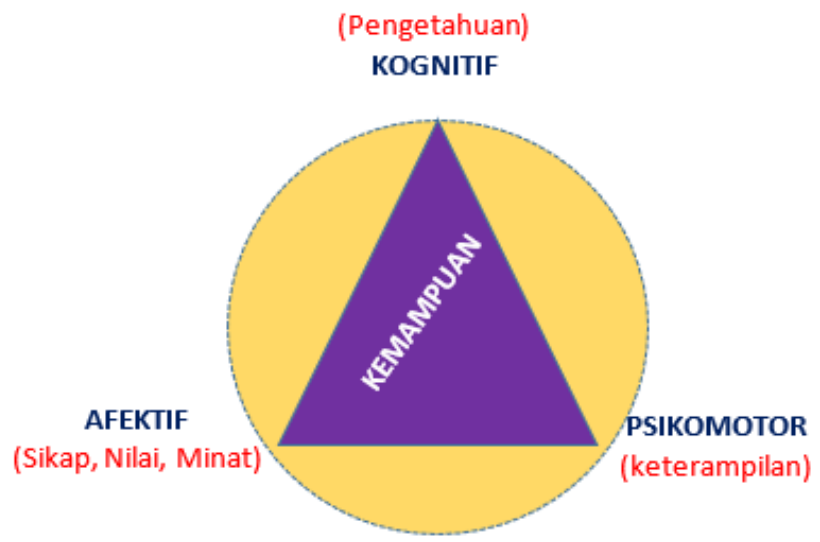

Gambar 2. Taksonomi bloom.

2.4 HardSkill Jurusan Rekayasa Perangkat Lunak (RFL).

Hardskill di bidang rekayasa perangkat lunak[13][14], kemampuan dasar seseorang sesuai bidang ilmu pengetahuan tertentu yang dimiliki oleh seorang lulusan SMK. Hardskill seorang lulusan SMK Kejuruan Bidang Rekayasa Perangkat Lunak (RPL) adalah:

a. Mampu menerapkan prinsip-prinsip teknik rekayasa/perekayasaan di dalam menyelesaikan permasalahan komplek di bidang teknologi informasi.

b. Mampu memilih metode yang tepat dalam rangka menyelesaikan masalah yang komplek di bidang teknologi informasi, berdasarkan pertimbangan akademik dan praktis, terhadap berbagai metode yang bisa digunakan.

c. Mampu merencanakan, menjalankan dan melaporkan kegiatan pengerjaan proyek perangkat lunak.

\subsection{SoftSkill SMK Jurusan Rekayasa Perangkat Lunak.}

Soft Skill di bidang rekayasa perangkat lunak adalah kemampuan lulusan dalam melakukan sosialisasi dengan team dan bisa bekerjasama dengan team dalam merencanakan, membangun proyek perangkat lunak[6][15][16][17][18],

a. Bisa beradaptasi dengan team dalam mengerjakan proyek perangkat lunak.

b. Bisa bekerja dengan team dalam proyek perangkat lunak.

c. Bisa bernegosiasi baik dengan team proyek ataupun dengan client.

d. Bisa memanfaatkan hardskill dengan baik dalam mengerjakan proyek perangkat lunak.

Standar kompetensi yang dimiliki oleh siswa SMK terkait dengan kejuruan keahlian praktis dalam pembuatan software perangkat lunak sesuai dengan Skema Sertifikasi KKNI Level II KKNI II Rekayasa Perangkat Lunak SKKNI 2004-240/ SKKNI 2016-rpl 282/TIK OP 01.002.02 pada tabel 1.

Tabel 1. Kompetensi pemrograman berorientasi objek[19].

\begin{tabular}{|c|c|c|}
\hline No & Kode Unit & Judul Unit Kompetensi \\
\hline \multicolumn{3}{|c|}{ KOMPETENSI UMUM DAN INTI } \\
\hline 1 & LOGOO0100201 & $\begin{array}{l}\text { Menerapkan prinsip keselamatan dan kesehatan kerja di } \\
\text { lingkungan kerja }\end{array}$ \\
\hline 2 & LOGOO0100101 & Menerapkan Sistem Mutu \\
\hline 3 & TIK OP010201 & Mengidentifikasi aspek kode etik dan HAKI di bidang TIK \\
\hline & IPETENSI FUNGs & \\
\hline
\end{tabular}


$5 \quad$ J62010001001

$6 \quad \mathrm{~J} 62010001201$

$7 \quad \mathrm{~J} 62010001802$

$8 \quad \mathrm{~J} 62010002002$

$9 \quad \mathrm{~J} 62010002302$

$10 \quad \mathrm{~J} 62010003002$

$11 \quad \mathrm{~J} 62010003302$

12 J62010004201

$13 \quad \mathrm{~J} 62010004601$
Menerapkan perintah eksekusi bahasa pemrograman berbasis Teks, Grafis dan Multimedia

Melakukan pengaturan software tools pemrograman

Mengimplementasikan pemrograman berorientasi objek

Menggunakan SQL

Membuat Dokumen Kode Program

Menerapkan Pemrograman Multimedia

Melaksanakan Pengujian Unit Program

Melaksanakan Konfigurasi Perangkat Lunak Sesuai Environment

Development Staging Production

Melakukan Logging Aplikasi

Sedangkan berdasarkan pengamatan penulis dalam PkM ini pada kondisi rata-rata kemampuan siswa SMK Jurusan Rekayasa Perangkat Lunak kalau di buat perbandingan berdasarkan analisis Taksonomi Anderson dan Krathwohl, Skill Professional, Prediksi Skill SMK Jurusan Rekayasa Perangkat Lunak (RPL) dan Kebutuhan DI/DU adalah seperti pada Tabel 2.

Tabel 2. Hasil komparasi skill jurusan RPL dengan skill Dunia Usaha (DI/DU).

\begin{tabular}{|c|c|c|c|c|c|c|}
\hline \multirow{2}{*}{$\begin{array}{l}\text { Taksonomi } \\
\text { Anderson \& } \\
\text { Krathwohl } \\
\text { Menciptakan } \\
\text { (Creating) }\end{array}$} & \multirow{2}{*}{$\begin{array}{l}\text { Professional Skill } \\
\text { - Mendesain GUI }\end{array}$} & \multicolumn{2}{|c|}{$\begin{array}{l}\text { Proyeksi Skill SMK } \\
\text { Jurusan RPL }\end{array}$} & \multicolumn{3}{|c|}{ Skill Yang dibutuhkan DI/DU } \\
\hline & & $\begin{array}{l}\text { - Mendesain } \\
\text { GUI }\end{array}$ & $\checkmark$ & \multicolumn{2}{|c|}{ - Mendesain GUI } & $\checkmark$ \\
\hline & - Mendesain field & $\begin{array}{l}\text { - Mendesain } \\
\text { field }\end{array}$ & $\checkmark$ & \multicolumn{2}{|c|}{ - Mendesain field } & $\checkmark$ \\
\hline & - Mendesain tabel & $\begin{array}{l}\text { - Mendesain } \\
\text { tabel }\end{array}$ & $\checkmark$ & \multicolumn{2}{|c|}{ - Mendesain tabel } & $\checkmark$ \\
\hline & $\begin{array}{l}\text { - Mendesain } \\
\text { database }\end{array}$ & $\begin{array}{c}\text { - Mendesain } \\
\text { database }\end{array}$ & $\checkmark$ & \multicolumn{2}{|c|}{ - Mendesain database } & $\checkmark$ \\
\hline & $\begin{array}{l}\text { - Membuat relasi } \\
\text { tabel }\end{array}$ & $\begin{array}{l}\text { - Membuat } \\
\text { relasi tabel }\end{array}$ & $\checkmark$ & \multirow{2}{*}{\multicolumn{2}{|c|}{$\begin{array}{l}\text { - Membuat relasi } \\
\text { tabel } \\
\text { - Membuat trigger }\end{array}$}} & $\checkmark$ \\
\hline & - Membuat trigger & $\begin{array}{l}\text { - Membuat } \\
\text { trigger }\end{array}$ & $\checkmark$ & & & $\checkmark$ \\
\hline & $\begin{array}{l}\text { - Mendesain logic } \\
\text { code dalam } \\
\text { menyelesaikan } \\
\text { masalah sesuai } \\
\text { bahasa program } \\
\text { yang digunakan }\end{array}$ & $\begin{array}{l}\text { - Mendesain } \\
\text { logic code } \\
\text { dalam } \\
\text { menyelesaika } \\
\text { n masalah } \\
\text { sesuai bahasa } \\
\text { program yang } \\
\text { digunakan }\end{array}$ & $\checkmark$ & $\begin{array}{l}\text { - Mendesain } \\
\text { code } \\
\text { menyelesaik } \\
\text { masalah } \\
\text { bahasa p } \\
\text { yang digunak }\end{array}$ & $\begin{array}{l}\text { logic } \\
\text { dalam } \\
\text { sesuai } \\
\text { ogram } \\
\text { an }\end{array}$ & $\checkmark$ \\
\hline $\begin{array}{l}\text { Mengevaluasi } \\
\text { (Evaluating) }\end{array}$ & $\begin{array}{c}\text {-Evaluasi proses } \\
\text { logika sesuai } \\
\text { dengan tujuan } \\
\text { pembuatan } \\
\text { perangkat lunak }\end{array}$ & $\begin{array}{l}\text {-Evaluasi } \\
\text { proses logika } \\
\text { sesuai dengan } \\
\text { tujuan } \\
\text { pembuatan } \\
\text { perangkat } \\
\text { lunak }\end{array}$ & $\otimes$ & $\begin{array}{l}\text {-Evaluasi } \\
\text { logika } \\
\text { dengan } \\
\text { pembuatan } \\
\text { perangkat lu }\end{array}$ & $\begin{array}{l}\text { proses } \\
\text { sesuai } \\
\text { tujuan } \\
\text { ak }\end{array}$ & $\checkmark$ \\
\hline
\end{tabular}


Uji Kompetensi Penguasaan Software Untuk Solusi Bisnis di Wilayah Kab. Bogor Sebagai Upaya Peningkatan Skill SMK Jurusan RPL

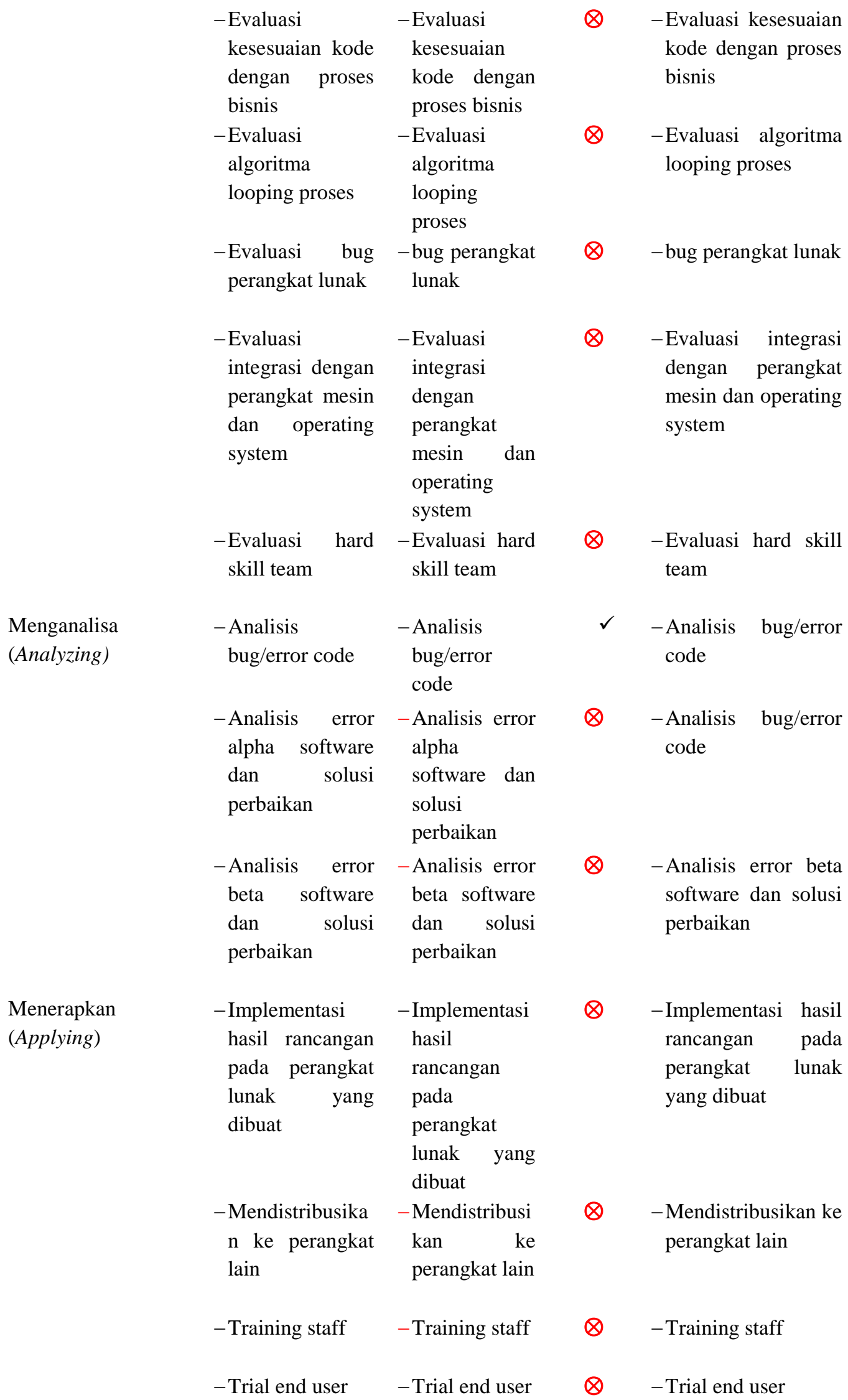




\begin{tabular}{|c|c|c|c|c|}
\hline $\begin{array}{l}\text { Memahami/Mengert } \\
\text { i (Understanding) }\end{array}$ & $\begin{array}{l}\text { - Memahami } \\
\text { Sintaks bahasa } \\
\text { program yang } \\
\text { digunakan } \\
\text { dalam } \\
\text { perancangan }\end{array}$ & $\begin{array}{l}\text {-Memahami } \\
\text { Sintaks } \\
\text { bahasa } \\
\text { program yang } \\
\text { digunakan } \\
\text { dalam } \\
\text { perancangan }\end{array}$ & $\checkmark$ & $\begin{array}{c}\text {-Memahami Sintaks } \\
\text { bahasa program } \\
\text { yang digunakan } \\
\text { dalam perancangan }\end{array}$ \\
\hline & $\begin{array}{l}\text { - Memahami } \\
\text { struktur bahasa } \\
\text { program yang } \\
\text { digunakan }\end{array}$ & $\begin{array}{l}\text { - Memahami } \\
\text { struktur } \\
\text { bahasa } \\
\text { program yang } \\
\text { digunakan }\end{array}$ & $\checkmark$ & $\begin{array}{l}\text { - Memahami struktur } \\
\text { bahasa program } \\
\text { yang digunakan }\end{array}$ \\
\hline & $\begin{array}{l}\text { - Memahami } \\
\text { konsep } \\
\text { pembangunan } \\
\text { perangkat lunak } \\
\text { (OOP) atau yang } \\
\text { lainya }\end{array}$ & $\begin{array}{l}\text {-Memahami } \\
\text { konsep } \\
\text { pembangunan } \\
\text { perangkat } \\
\text { lunak (OOP) } \\
\text { atau yang } \\
\text { lainya }\end{array}$ & $\checkmark$ & $\begin{array}{l}\text {-Memahami konsep } \\
\text { pembangunan } \\
\text { perangkat lunak } \\
\text { (OOP) atau yang } \\
\text { lainya }\end{array}$ \\
\hline & $\begin{array}{l}\text { - Paham terkait } \\
\text { metode } \\
\text { pengembangan } \\
\text { Perangkat lunak } \\
\text { (SDLC/WaterFa } \\
\text { ll) }\end{array}$ & $\begin{array}{l}\text {-Memahami } \\
\text { salah satu atau } \\
\text { lebih metode } \\
\text { pengembanga } \\
\text { n Perangkat } \\
\text { lunak } \\
\text { (SDLC/Water } \\
\text { Fall }\end{array}$ & $\checkmark$ & $\begin{array}{l}\text {-Memahami salah } \\
\text { satu atau lebih } \\
\text { metode } \\
\text { pengembangan } \\
\text { Perangkat lunak } \\
\text { (SDLC/WaterFall }\end{array}$ \\
\hline $\begin{array}{l}\text { Mengingat } \\
\text { (Remembering) }\end{array}$ & $\begin{array}{l}\text { - Mendeskripsika } \\
\mathrm{n} \text { tugas-tugas } \\
\text { proyek } \\
\text { pembuatan } \\
\text { software dalam } \\
\text { manajemen } \\
\text { proyek } \\
\text { perangkat lunak } \\
\text {-Mengidentifikas } \\
\text { i kebutuhan } \\
\text { dalam proyek } \\
\text { pembuatan } \\
\text { perangkat lunak. }\end{array}$ & $\begin{array}{l}\text {-Mendeskripsi } \\
\text { kan tugas- } \\
\text { tugas proyek } \\
\text { perangkat } \\
\text { lunak dalam } \\
\text { manajemen } \\
\text { proyek } \\
\text { perangkat } \\
\text { lunak } \\
\text {-Mengidentifik } \\
\text { asi kebutuhan } \\
\text { dalam proyek } \\
\text { pembuatan } \\
\text { perangkat } \\
\text { lunak. }\end{array}$ & $\otimes$ & $\begin{array}{l}\text { - Mendeskripsikan } \\
\text { tugas-tugas proyek } \\
\text { perangkat lunak } \\
\text { dalam manajemen } \\
\text { proyek perangkat } \\
\text { lunak } \\
\text { - Mengidentifikasi } \\
\text { kebutuhan dalam } \\
\text { proyek pembuatan } \\
\text { perangkat lunak. }\end{array}$ \\
\hline
\end{tabular}

Berdasarkan latar belakang di atas bahwa dalam meningkatkan kompetensi lulusan SMK Jurusan Rekayasa Perangkat Lunak perlu adanya dukungan teknologi dan kompetensi dari Pengajar. Oleh karena itu dalam Pengabdian kepada Masyarakat ini melakukan uji kompetensi terkait perencanaan di bidang strategis dan teknis dalam peningkatan kompetensi siswa supaya bisa berdaya saing dan supaya menjadi tenaga siap pakai di DI/DU [20].

\section{HASIL DAN PEMBAHASAN}

\subsection{Analisis SWOT}


Uji Kompetensi Penguasaan Software Untuk Solusi Bisnis di Wilayah Kab. Bogor

Sebagai Upaya Peningkatan Skill SMK Jurusan RPL

Analisa SWOT digunakan untuk kondisi lingkungan internal dan eksternal dalam memberi masukan pada manajemen pengambilan keputusan terkait dengan strategi dan prioritas yang harus didahulukan.

Tabel 2. Analisis SWOT.

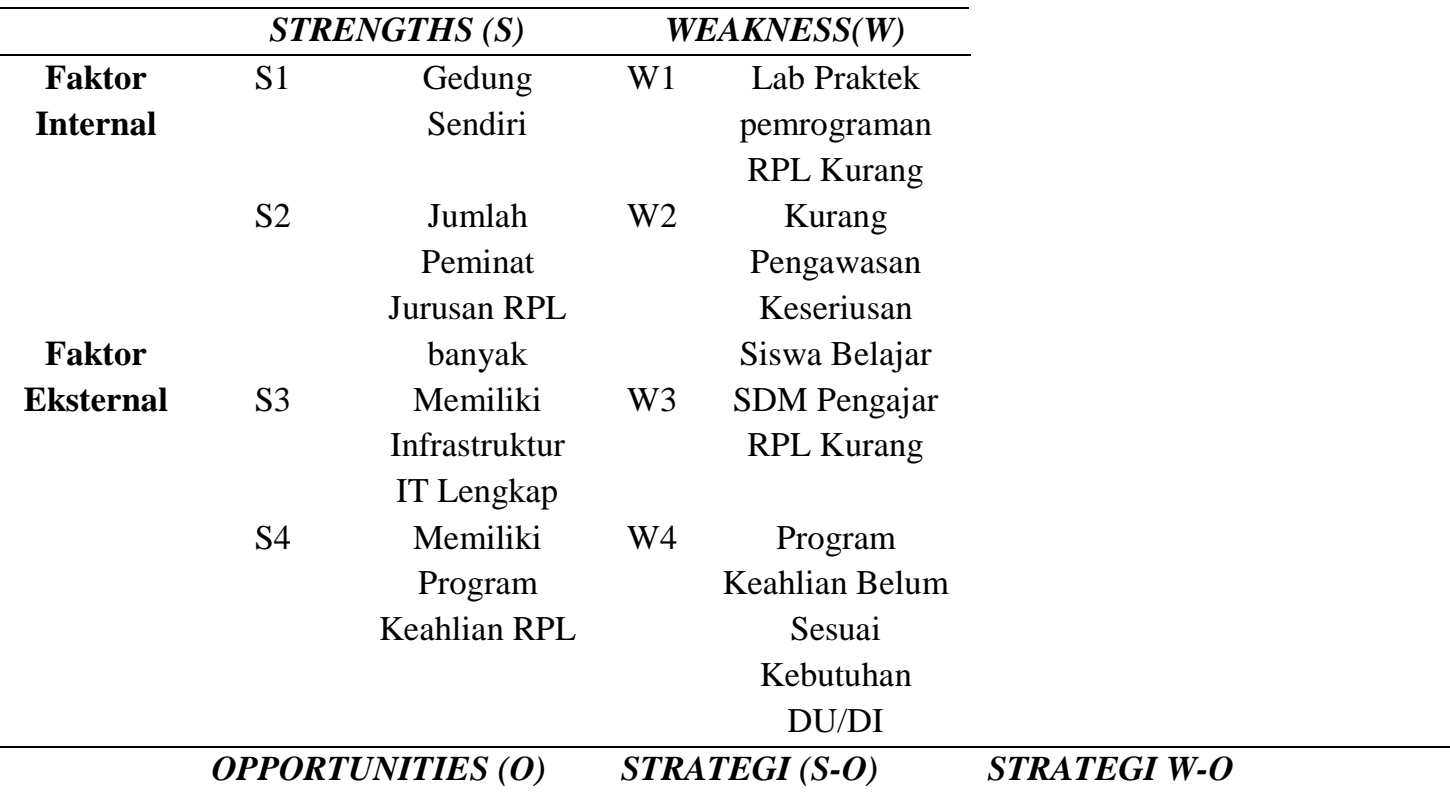

\begin{tabular}{|c|c|c|c|c|c|}
\hline 01 & $\begin{array}{l}\text { Banyak minat dari lulusan } \\
\text { SMK Jurusan RPL }\end{array}$ & SO1 & $\begin{array}{l}\text { Melakukan } \\
\text { promosi baik } \\
\text { secara offline } \\
\text { maupun online }\end{array}$ & WO1 & $\begin{array}{l}\text { Meningkatkan sarana } \\
\text { dan prasarana untuk } \\
\text { Peningkatan Skill } \\
\text { Siswa RPL }\end{array}$ \\
\hline $\mathrm{O} 2$ & Lokasi Sekolah Strategis & & & WO2 & $\begin{array}{l}\text { Menyediakan } \\
\text { pendampingan terkait } \\
\text { dengan keahlian RPL }\end{array}$ \\
\hline & & & Memfasilitasi & & Menambah Software \\
\hline \multirow[t]{3}{*}{$\mathbf{O 3}$} & \multirow[t]{2}{*}{$\begin{array}{l}\text { Program keahlian } \\
\text { memenuhi Kebutuhan } \\
\text { DU/DI untuk bidang TIK- } \\
\text { ICT ( Programmer) }\end{array}$} & $\mathrm{SO} 2$ & $\begin{array}{l}\text { Siswa untuk } \\
\text { melakukan } \\
\text { PKL/Magang di } \\
\text { Perusahaan } \\
\text { Software House } \\
\text { atau DI/DU } \\
\text { pengembang } \\
\text { Perangkat } \\
\text { Lunak }\end{array}$ & WO3 & $\begin{array}{l}\text { Sistem DBMS dan } \\
\text { Bahasa Pemrograman } \\
\text { yang dibutuhkan atau } \\
\text { lagi trend di DU/DI. }\end{array}$ \\
\hline & & & & WO4 & $\begin{array}{l}\text { Menyediakan } \\
\text { penelusuran } \\
\text { Jurusan RPL }\end{array}$ \\
\hline & THREATS (T) & & $\begin{array}{l}\text { STRATEGI S- } \\
\mathrm{T}\end{array}$ & & STRATEGI W-T \\
\hline
\end{tabular}


T1

Pesaing dari sekolah lain Jurusan RPL

Permintaan lulusan

T2

T3

T4 kualitas tinggi dari pemerintah dan DU/DI

Kebutuhan TIK-ICT

Memonitor Kebijakan

Pemerintah Terkait

Standar Skill Keahlian bidang TIK-ICT /DU/DI

Perkembangan Teknologi Software terus meningkat
Meningkatkan

ST1 Skill Lulusan Jurusan RPL

$\begin{array}{ll} & \text { Manajemen } \\ \text { ST2 } & \begin{array}{l}\text { Sekolah } \\ \text { melakukan }\end{array} \\ & \text { update } \\ \text { kebijakan } \\ \text { pemerintah } \\ \text { Kurikulum } \\ \text { selalu mengikuti } \\ \text { kemajuan } \\ \text { teknologi } \\ \text { terbaru sesuai } \\ \text { dengan } \\ \text { kebutuhan } \\ \text { Perusahaan } \\ \text { dunia usaha }\end{array}$

Meningkatkan Tenaga

WT1 Pendidik terkait RPL

dalam meningkatkan

SDM di bidang

Pengembangan

Perangkat Lunak
Mensosialisasikan

WT2 pada tenaga pengajar tentang perkembangan TIK-ICT terbaru

Mengadakan studi tentang keperluan sistem perangkat lunak yang digunakan perusahaan

4.2. Analisis PEST.

Analisis SWOT digunakan ini mampu karena ditunjang metode analisis PEST, dimana kondisi pendidikan dalam lingkungan dipengaruhi oleh faktor politik, ekonomi, kondisi pendidikan dan perkembangan teknologi.

A. Politik.

1) Berhubungan dengan peran perundang-undang pendidikan nasional.

2) Berhubungan dengan kondisi kurikulum yang disesuaikan dengan standar nasional.

3) Kementerian pendidikan nasional melakukan pengawasan pada SMK, dalam hal ini dinas pendidikan wilayah IV Kab. Bogor.

4) Kerjasama dengan institusi pendidikan dengan institusi/lembaga dalam bidang TIK dengan stakeholder di perusahaan.

B. Ekonomi.

1) Minat dan daya beli masyarakat tentang minat menyekolahkan pada jenjang pendidikan yang lebih tinggi.

2) Memberikan beasiswa pada siswa berprestasi.

3) Melakukan pengabdian pada masyarakat.

C. Sosial.

Melakukan bakti sosial pendidikan dan kesadaran tentang pendidikan

D. Teknologi.

Penggunaan teknologi TIK seperti Elearning, E-Library dan aplikasi pembelajaran dengan multimedia.

\subsection{Analisa CSF.}

Dalam analisa CSF ini hanya digunakan 3 unsur dalam Balance Scored diantaranya: 
Uji Kompetensi Penguasaan Software Untuk Solusi Bisnis di Wilayah Kab. Bogor

Sebagai Upaya Peningkatan Skill SMK Jurusan RPL

A. Internal Bisnis: memfokuskan pada kinerja internal manajemen sekolah dalam mendorong usaha manajemen sekolah.

Tabel 3. Internal bisnis.

\begin{tabular}{|c|c|c|c|c|}
\hline Item & Sasaran & $\begin{array}{c}\text { Ukuran } \\
\text { Penilaian }\end{array}$ & $\begin{array}{c}\text { CSF } \\
\text { (Tindakan) }\end{array}$ & Solusi \\
\hline \multirow[t]{2}{*}{$\begin{array}{l}\text { Internal } \\
\text { bisnis }\end{array}$} & $\begin{array}{l}\text { Update } \\
\text { kurikulum }\end{array}$ & $\begin{array}{l}\text { Kualitas } \\
\text { kurikulum }\end{array}$ & $\begin{array}{l}\text { Kurikulum sesuai } \\
\text { dengan kompetensi } \\
\text { dunia kerja pada } \\
\text { bidang RPL }\end{array}$ & $\begin{array}{l}\text { Update } \\
\text { informasi untuk } \\
\text { lowongan di } \\
\text { bidang RPL } \\
\text { untuk lulusan } \\
\text { SMK RPL }\end{array}$ \\
\hline & $\begin{array}{l}\text { Meningkatkan } \\
\text { kompetensi } \\
\text { Tendik (tenaga } \\
\text { pendidik) }\end{array}$ & $\begin{array}{l}\text { Kualitas } \\
\text { Tendik di } \\
\text { bidang } \\
\text { RPL }\end{array}$ & $\begin{array}{l}\text { Tersedianya SDM } \\
\text { yang memiliki } \\
\text { kompetensi }\end{array}$ & $\begin{array}{l}\text { Diadakannya } \\
\text { pelatihan untuk } \\
\text { tenaga pendidik } \\
\text { tentang } \\
\text { pemrograman } \\
\text { yang dibutuhkan } \\
\text { di DU/DI }\end{array}$ \\
\hline
\end{tabular}

B. Customer: berfokus pada kepuasan pelanggan. Dalam kasus ini pelanggan yaitu DI/DU, siswa dan orang tua siswa.

Tabel 4. Customer.

\begin{tabular}{|c|c|c|c|c|}
\hline Aspek & Sasaran & $\begin{array}{c}\text { Ukuran } \\
\text { Penilaian }\end{array}$ & $\begin{array}{c}\text { CSF } \\
\text { (Tindakan) }\end{array}$ & Solusi \\
\hline \multirow[t]{3}{*}{ Customer } & $\begin{array}{l}\text { Peningkatan } \\
\text { hubungan } \\
\text { dengan } \\
\text { perusahaan } \\
\text { DU/DI di } \\
\text { bidang RPL }\end{array}$ & $\begin{array}{l}\text { Berapa } \\
\text { banyak } \\
\text { kerjasama } \\
\text { dengan } \\
\text { perusahaan } \\
\text { terkait dengan } \\
\text { bidang RPL }\end{array}$ & $\begin{array}{l}\text { Penambahan } \\
\text { tempat siswa } \\
\text { untuk } \\
\text { magang/pkl } \\
\text { di bidang } \\
\text { RPL }\end{array}$ & $\begin{array}{l}\text { Update informasi } \\
\text { terkait perusahaan yang } \\
\text { membutuhkan Lulusan } \\
\text { RPL }\end{array}$ \\
\hline & $\begin{array}{l}\text { Peningkatan } \\
\text { siswa Lulusan } \\
\text { Jurusan RPL } \\
\text { yang terserap } \\
\text { di perusahaan }\end{array}$ & $\begin{array}{l}\text { Berapa } \\
\text { banyak } \\
\text { lulusan yang } \\
\text { bekerja } \\
\text { bidang RPL }\end{array}$ & $\begin{array}{l}\text { Peningkatan } \\
\text { Jumlah } \\
\text { lulusan } \\
\text { Jurusan RPL } \\
\text { yang terserap }\end{array}$ & $\begin{array}{l}\text { Adanya telusur alumni } \\
\text { pada lulusan RPL yang } \\
\text { sudah bekerja pada } \\
\text { bidang RPL }\end{array}$ \\
\hline & $\begin{array}{l}\text { pada bidang } \\
\text { RPL } \\
\text { Kepuasaan } \\
\text { siswa jurusan } \\
\text { dan orangtua } \\
\text { jurusan RPL }\end{array}$ & $\begin{array}{l}\text { Kualitas } \\
\text { keahlian/skill } \\
\text { jurusan RPL }\end{array}$ & $\begin{array}{l}\text { Kepuasan } \\
\text { pelayanan } \\
\text { lembaga }\end{array}$ & $\begin{array}{l}\text { Memfasilitasi } \\
\text { hubungan kerjasama } \\
\text { yang baik dengan } \\
\text { orang tua siswa dan } \\
\text { orang tua alumni }\end{array}$ \\
\hline
\end{tabular}


C. Learning and Growth memfokuskan pada pengembangan pembelajaran dengan mempertimbangkan institusi organisasi dan keadaan infrastruktur untuk kemajuan manajemen khususnya Jurusan RPL.

Tabel 5. Learning and Growth.

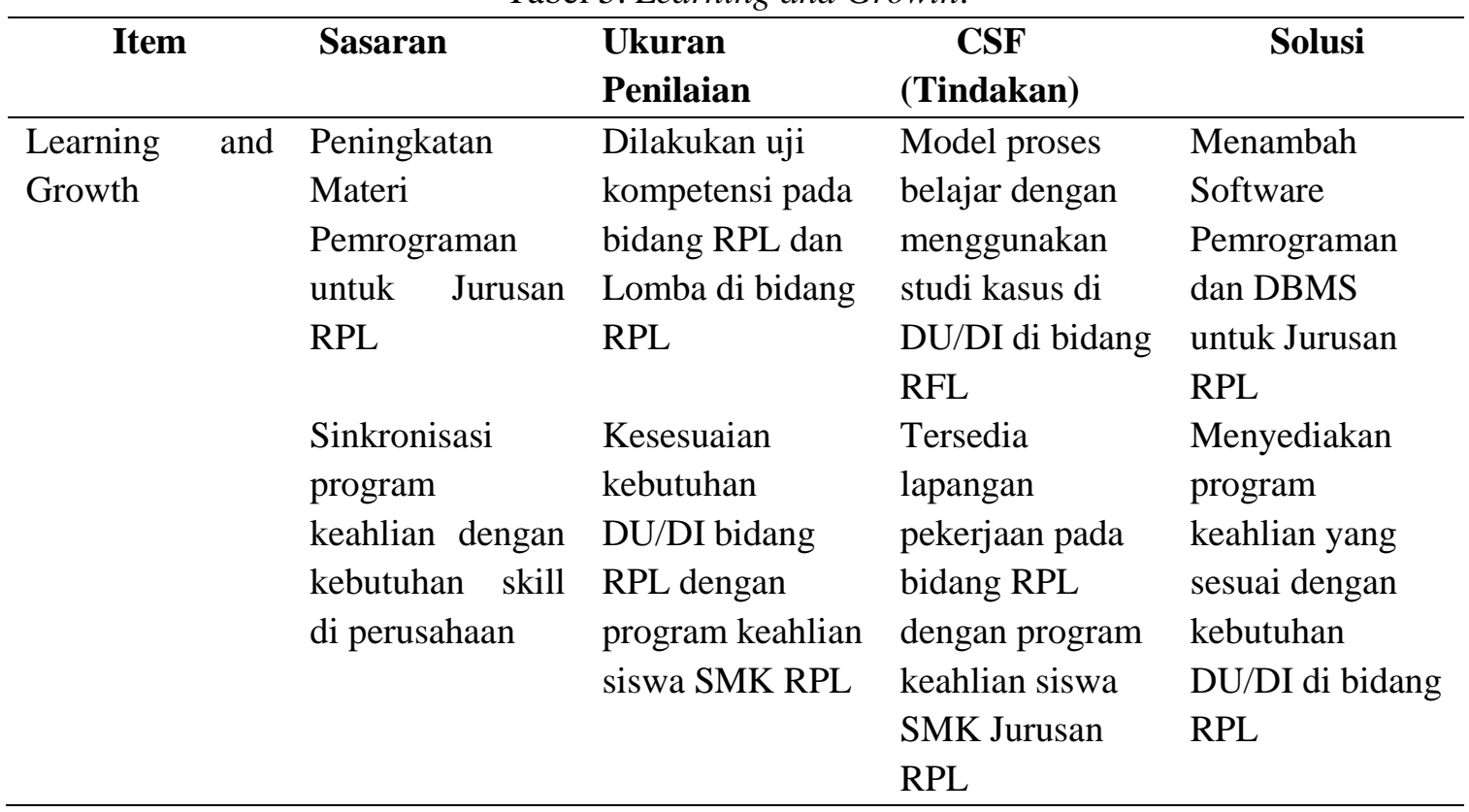

D. Hasil Perumusan Strategi

Analisa kebutuhan potensial dalam rangka peningkatan mutu skill lulusan SMK Jurusan RFL.

1) Penambahan perangkat software mengikuti kebutuhan DU/DI baik bahasa pemrograman ataupun sistem database manajemen (DBMS).

2) Perubahan kurikulum dan modul pembelajaran siswa berbasis pada project yang dibutuhkan di DU/DI.

3) Peningkatan kompetensi dari pendidik atau dari praktisi/pelaku pengembang perangkat lunak.

4) Penambahan fasilitas untuk magang siswa dalam bidang RPL dengan DU/DU atau perusahaan pengembang software.

Adapun berdasarkan hasil kompetensi setiap perwakilan peserta SMK Se-Kab Bogor, sebanyak 12 peserta yang mewakili sekolahnya masing masing dikelompokan pada tiga kategori desain database, desain form dan database.

E. Hasil lomba hasil uji kompetensi seperti terlihat pada gambar 3.

1) Total nilai kompetensi secara keseluruhan software solution for business.

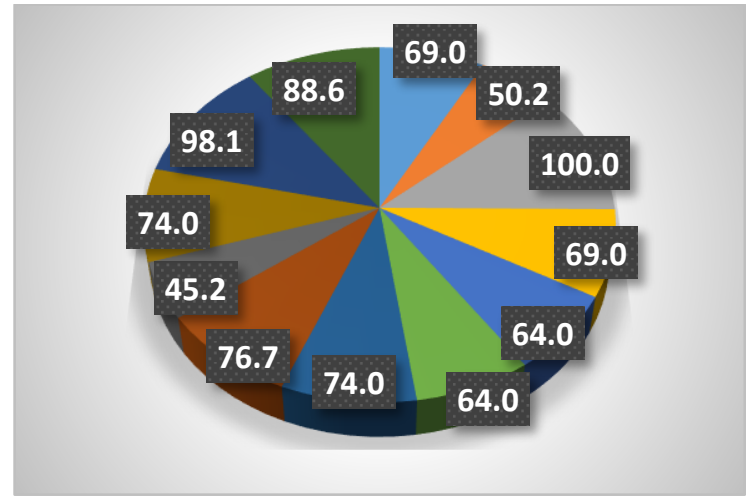

Gambar 3. Grafik total nilai hasil uji kompetensi. 
Uji Kompetensi Penguasaan Software Untuk Solusi Bisnis di Wilayah Kab. Bogor

Sebagai Upaya Peningkatan Skill SMK Jurusan RPL

2) Perbandingan ketiga komponen dari materi yang dilombakan menghasilkan untuk komponen: desain interface $(25.85 \%)$, database $(23,75 \%)$ dan Coding $(23,17 \%)$ dari nilai total perhitungan.

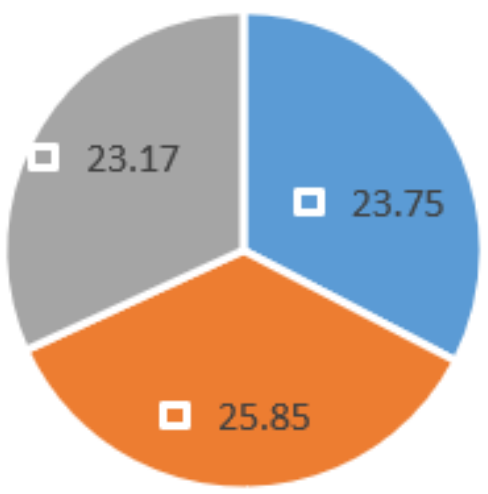

Gambar 4. Grafik nilai hasil uji kompetensi perbandingan 3 komponen.

\section{5) SIMPULAN}

Setelah melakukan pengabdian kepada masyarakat dari tanggal 30 oktober sampai dengan 31 oktober 2020 dengan peserta uji kompetensi sebanyak 12 peserta yang mewakili 12 SMK di wilayah Kabupaten Bogor bertempat di SMK Bina Mandiri Multimedia Cileungsi menghasilkan gambaran tentang kondisi skill dari siswa SMK khususnya jurusan RPL, dari 3 (tiga) penilain yang dilombakan database, desain form dan coding program memberikan gambaran tentang kondisi skill lulusan SMK Jurusan RPL dirasa masih kurang sinkron dengan kebutuhan di DU/DI sehingga jumlah lulusan belum terserap dengan baik. Setelah diadakan PkM ini dengan mengetahui kelebihan dan kekurangan yang ada dan juga dilakukan pembenahan pada sistem modul kurikulum berbasis kompetensi DU/DI, peningkatan kompetensi pendidik dan memfasilitasi magang pada bidang RPL sehingga bisa meningkatkan Skill siswa SMK di Wilayah Kab. Bogor Khususnya Kopertis Wilayah IV.

\section{6) UCAPAN TERIMA KASIH.}

Dalam penyampaian ucapan terima kasih ini disampaikan pada seluruh pihak yang telah berkontribusi dalam PkM ini.

a. SMK Bina Mandiri Multimedia Cileungsi.

b. Ketua LPPM Sekolah Tinggi Teknologi Muhammadiyah Cileungsi.

c. Dinas Pendidikan Kab. Bogor Kopertis Wilayah IV.

\section{7) DAFTAR PUSTAKA}

[1] S. Erlinda, K. Andesa, and T. Nasution, "Peningkatan Kemampuan Pemrograman AJAX dan jQuery Melalui Pelatihan di SMK Negeri 1 Pagaran Tapah Darussalam,” pp. 1-9, 2020.

[2] Arina Hidayati, "Relevansi Kompetensi Lulusan Sekolah Menengah Kejuruan Dengan Kebutuhan Dunia Usaha dan Industri," in Prosiding Seminar Nasional Pendidikan Ekonomi \& Bisnis, 2015, vol. ISBN-978-6.

[3] T. Kandaga, "Analisis dan Perancangan Bahasa Pemrograman Paralel Beserta Pembuatan Prototipe Kompilatornya," J. Inform., vol. 1, no. 1, pp. 53-76, 2005.

[4] D. S. W. K. Sutrisno, "Relevansi soft skill yang dibutuhkan dunia usaha/industri dengan yang dibelajarkan di sekolah menengah kejuruan," Teknol. dan Kejuru., vol. 36, no. 2, pp. 107-118, 2013

[5] D. I. Prasetyo, A. D. Herlambang, and S. H. Wijoyo, "Kesenjangan Profil Antara Hard Skills dan Soft Skills Lulusan SMK Jurusan Rekayasa Perangkat Lunak dengan Kebutuhan Industri 
Bidang Teknologi Informasi di Kota Malang,” vol. 4, no. 9, pp. 2902-2911, 2020.

[6] M. Ali, "Evaluasi Softskill Mahasiswa Berbasis Android Dengan Algoritma Dynamic Programming," J. Elektron. Sist. Inf. Dan Komput., vol. 1, no. 1, pp. 226-232, 2017.

[7] A. Dharmanto, A. Saepudin, H. Sholih, W. Pracoyo, and W. Arso, "Pelatihan Mengelas Bagi Karang Taruna dan Remaja Putus Sekolah Di Kecamatan Cileungsi," Educivilia J. Pengabdi. pada Masy., vol. 1, no. 2, p. 131, 2020.

[8] N. Maula, "PENGARUH EKSTERNAL PADA PERUSAHAAN START-UP BIDANG PENDIDIKAN: PENGGUNAAN TEKNIK ANALISIS PEST DI CV . BIG EDU INDONESIA," Khazanah Intelekt., vol. 4, no. 2020, pp. 645-658, 2020.

[9] I. Widiaty, "Relevansi Kurikulum Smk Berbasis Industri Kreatif Dengan Metode Extrapolation and the Econometric Approach," Innov. Vocat. Technol. Educ., vol. 9, no. 1, pp. 29-42, 2017.

[10] N. Wibowo, "UPAYA MEMPERKECIL KESENJANGAN KOMPETENSI LULUSAN," pp. 45-50, 2015.

[11] W. Wilarso, A. Afriliyanti, J. Juniadi, and M. Mujiarto, "Competency Test of Engineering Drawing Design Engineering Using the Online Method,” J. Dedik., vol. 17, no. 1, p. 30, 2020.

[12] I. Gunawan and A. R. Paluti, "TAKSONOMI BLOOM - REVISI RANAH KOGNITIF: KERANGKA LANDASAN UNTUK PEMBELAJARAN, PENGAJARAN, DAN PENILAIAN,” E-Journal.Unipma, vol. 7, no. 1, pp. 1-8, 2017.

[13] S. K. Ningrum and Djuniadi, "Penguatan Konsep Pemrograman Berorientasi Objek Siswa kelas XI RPL SMKN 2 Semarang,” Edu Komputika J., vol. 5, no. 1, pp. 33-43, 2019.

[14] M. I. Athariq, T. Andayono, P. Studi, and P. Teknik, "PRAKTEK KERJA INDUSTRI SISWA KELAS XII SMK NEGERI 1 LINTAU BUO," vol. 6, no. 2, pp. 1-6.

[15] S. Mariah and M. Sugandi, "KESENJANGAN SOFT SKILLS LULUSAN SMK DENGAN KEBUTUHAN TENAGA KERJA DI INDUSTRI,” Sociol. Work An Encycl., pp. 1-26, 2013.

[16] F. Delita, Elfayetti, and Tumiar Sidauruk, "PENINGKATAN SOFT SKILLS DAN HARD SKILLS MAHASISWA MELALUI PROJECT-BASED LEARNING PADA MATA KULIAH PERENCANAAN PEMBELAJARAN GEOGRAFI Fitra," vol. 8, no. 2, pp. 124-135, 2016.

[17] A. P. Sasmito, D. Kustono, and S. Patmanthara, "Kesiapan memasuki dunia usaha/dunia industri (du/di) siswa paket keahlian rekayasa perangkat lunak di smk," vol. 38, no. 1, pp. 25-40, 2015.

[18] A. Saepudin, H. Sholih, W. Pracoyo, A. Dharmanto, and W. Wilarso, "Welding Training for Youth Organization in Dayeuh Village," J. Dedik., vol. 17, no. 1, p. 39, 2020.

[19] BNSP, "Skema-Sertifikasi-KKNI-Level-II." pp. 1-4, 2017.

[20] A. Surya, F. Azharul, W. Wilarso, M. Idris, Y. Z. Azziqi, and I. H. Retno, "Improving High School and Vocational School Teachers in Writing Skill," J. Dedik., vol. 17, no. 1, p. 64, 2020. 